\title{
Perkawinan Eksogami dan Dampaknya dalam Sejarah Bali Kuna (Sebuah Studi Kasus)
}

\section{Made Jaya}

Keywords: exogamy, marriage, inscription, ancient manuscripts, history, Old Bali

\section{How to Cite:}

Jaya, I. M. Perkawinan Eksogami dan Dampaknya dalam Sejarah Bali Kuna (Sebuah Studi Kasus). Berkala Arkeologi, 14(2), 148-150.

https://doi.org/10.30883/jba.v14i2.714

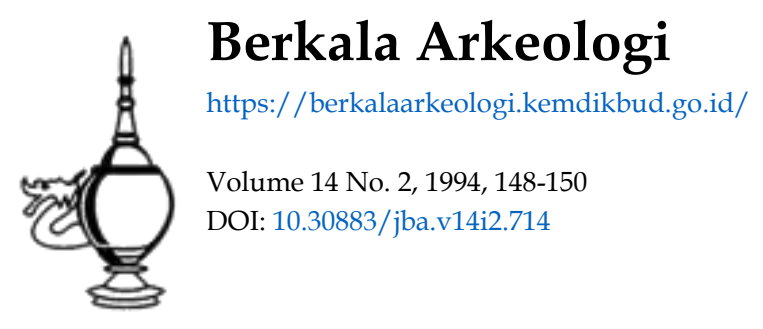

\section{(c) (i) (2) (2)}

This work is licensed under a Creative Commons Attribution-NonCommercial-ShareAlike 4.0 International License. 


\title{
PERKAWINAN EKSOGAMI DAN DAMPAKNYA DALAM SEJARAH BALI KUNA (Sebuah Studi Kasus)
}

\author{
I Made Jaya \\ (Balai Arkeologi Denpasar)
}

1

Manusıa tidak ada yang terlepas dari ikatan adat istiadat yang lazim berlaku pada masyarakatnya sebagai batasan kebiasaan hidup individu. Semuanya ini diatur sesuai norma dan tingkat hidup tertentu: yang pada akhirnya dapat dipakai sebagai landasan melaksanakan tatanan hidup bermasyarakat dan bernegara Peri kehidupan seperti ini tercermin pada saat menginjak masa kanak-kanak, remaja, masa perkawinan, dan masa hamil. Proses dari masa kanak-kanak menginjak masa remaja, dan remaja menuju masa berkeluarga senantiasa dilaksanakan upacara selamatan. Upacara pada saat peralihan sepanjang siklus hidup manusia itu bersifat universal, dan terdapat dalam semua kehidupan manusia, hanya saja tidak semua saat peralihan itu dianggap sama pentingnya. Pada siklus hidup manusia yang terpenting adalah proses dari manusia itu mengakhiri masa remajanya menuju hidup berumah tangga. Proses penting inilah yang disebut dengan istilah perkawinan atau nikah.

Dipandang dari sudut kebudayaan, perkawinan berkaitan dengan keterikatan seseorang dalam membina rumah tangga. Selain dipandang darı kebutuhan hidup, perkawinan juga mempunyai berbagai fungsi di dalam kehidupan masyarakat. Dalam perkawinan terdapat hak dan kewajiban, antara lain memberikan perlindungan kepada anak-anaknya, terlepas dari hidup kesepıan. memenuhi kebutuhan harta benda, mendapatkan status dan hak di masyarakat, dan hubungan baik di antara kelompok-kelompok tertentu (Wardha,1992-2-3). Akibat perkawinan itu, maka terbentuklah rumah tangga sebagai satu kesatuan sosial. Dalam berumah-tangga, seseorang menJadi lebih bertanggung-jawab dan mandiri. Segalanya diatur secara bersama-sama antara lain. makan ber-sama, tidur bersama, memecahkan segala per-masalahan secara bersama (yang dikenal dengan nama kurn (kuren)).

Berdasarkan banyaknya konsekuensi dalam perkawinan tersebut, maka hampir semua masyarakat mempunyai batasan-batasan untuk memilih jodoh (calon istri / suami). Adat masyarakat tertentu menganut bahwa seseorang tidak boleh berjodoh dengan saudara sekandung, saudara sepupu dari pihak ayah, saudara perempuan dari pihak ayah dan kawin bertukar, artinya perkawinan antara saudara perempuan suamide- ngan saudara laki-laki istri. Lain halnya kalangan masyarakat di Bali, seseorang harus kawın dengan orang sedesanya sendiri, atau harus kawın dengan orang yang sama klennya, dan dianggap sebagai satu keturunan (tunggal kawitan atau tunggal dadia). Sedangkan di Mentawai perkawinan dalam suku yang sama atau satu uma sangat dilarang, walaupun orang seuma itu telah berada di luar daerah. Ketentuan seperts itupun terdapat pada suku Batak, dimana seseorang dilarang kawin dengan saudara semarganya sendiri. Perkawinan satu marga dianggap melanggar hukum adat (Izarwisma M., 1992).

Dalam makalah ini akan dibicarakan mengenai perkawinan eksogami, dan sebagai studi kasus adalah Perkawinan Gunapriyadharmapatni dengan Dharma Udayana Warmadewa Dikatakan perkawinan eksogami karena Gunapriyadharmapatni yang nama kecilnya Mahendradata berasal dari klen/dinasti Isana (Jawa TImur), sedangkan Dharma Udayana Warmadewa berasal dari klen/dinasti Warmadewa di Bali

Dalam penelitian sejarah kuna dinyatakan bahwa perkawinan Gunapriyadharmapatni dengan Oharma Udayana Warmadewa telah menghasilkan tiga (3) orang putera yaitu; Erlangga, Marakata, dan Anak Wungsu. Dengan demikıan ketiga putera raja inilah yang memegang tampuk pemerintahan selanjutnya di Bali (ahli waris).

Sumber data yang digunakan dalam upaya menyusun tulisan ini adalah prasasti-prasastı yang terbit sekitar abad $X-1 X M$, serta beberapa naskah-naskah kuna seperti Negarakertagama, Pararaton, dan Calon Arang.

\section{II}

Sebelum melangkah pada pokok bahasan, perlu dicatat bahwa sebelum pemerintahan raja Gunapriyadharmapatni bersama Dharma Udayana hubungan Jawa-Bali telah terjalin. Bukti ini dapat diketahui dari sebagian isi prasasti KubuKubu 1 b IVa. 4 - 4b. 1 yaitu sebagai berikut.

"-geng nyambak rakıyan hujung mwang reke maja (5) wuntin an dinulu sira mangngdona mare bantan, de sang mapatih, alah pwa ikang bantan denira nahan matangnyarpanadahakenya (IV b 1) anugraha i sri maharaja- (Boechari, 1962)

Prasasti yang dikeluarkan oleh raja Balitung (899-911 M) di Jawa Tengah ini bertahun $905 \mathrm{M}$, memberikan gambaran kepada kita bahwa Rakryan Hujung (Dyah Manarak) dan Raka 
Majawuntan menerima anugrah raja karena telah menyerang Bantan serta berhasil mengalahkannya. Sampai sekarang tampaknya belum ada kesamaan pendapat mengenai kata Bantan tersebut. Asumsi muncul dari sebuah penelitian yang dilakukan oleh Wardha (Fakultas Sastra Universitas Udayana) yang memberi petunjuk kuat bahwa yang dimaksud Bantan dalam prasasti Kubu-kubu itu adalah Pulau Bali sendiri (Wardha, 1987; 1991: 1-13, lampiran 1 dan 2).

Hubungan Jawa dengan Bali tercantum pula pada prasasti Gobleg (982 masehi) yang diterbitkan oleh Sri Maharaja Sri Wijaya Mahadewi (Goris, 1954a). Berdasarkan unsur-unsur penamaan serta jabatan-jabatan, memberi indikasi bahwa ratu ini merupakan keturunan Sri Wijaya dari Sumatera (Callenfels, 1924: 3). Sedangkan Damais (1955:227) dan Goris (1965:21-22) menyebut bahwa putri ini adalah anak dari Empu Sindok. Hal ini dikuatkan oleh prasasti Pucangan bertahun 1041 M (Kern,1917). Hubungan selanjutnya terjadi pada saat pemerintahan raja Gunapriya-dharmapatni antara 989 - 1011 M.

Di dalam sejarah Bali kuna deretan nama dari keluarga Udayana memegang peranan cukup penting. Dari penelitian tim Jurusan Arkeologi Fakultas Sastra Universitas Udayana, didapat informasi bahwa pada sebuah candi atau permandian di desa Biting, yang terletak di gunung Bekel di lereng gunung Penanggungan (Jawa Timur), oleh masyarakat setempat disebut candi Triloka. Pada bagian bawah tembok permandian Jalatunda terdapat tulisan "Udayana" (Ardana dkk, 1984). Tulisan-tulisan yang tertera berbentuk huruf Kadirı kwadrat, sejenis dengan huruf yang terdapat pada candi Tebing (Gua - garbha) dan candi Gunung Kawi, Tampaksiring, di Kabupaten Gianyar Selanjutnya disebutkan bahwa masingmasing tulisan tersebut, satu dengan yang lain terdapat pemisahan yang menyebabkan kata "Udayana" seakan-akan tidak ada hubungan. Di samping itu bentuk hurufnya berbeda-beda, ada yang besar dan ada yang kecil. Komposisi huruf sepeiti itu menyebabkan adanya perbedaan dari para ahli dalam menginterpretasikan apa yang ada (Galestin, 1964).

Asumsi muncul dengan melihat; pertama angka tahun (saka) 899; ke-dua kata "meragayawatr"; ke-tiga kata gempeng; dan ke-empat kata "Udayana". Kata "m(e)ragayawati" kalau dipisahkan akan menjadi me-raga-ya-wati. Secara etimologi kata raga berarti; nafsu, jatuh cinta, cinta kasih, semara, rimang, badan, tubuh, raga, dan lain-lain (Juynboll, 1923:452; Wojowasito, 1973 : 234; Prawiroatmojo, 1981:125; Mardiwarsito, 1981:456; Warna dkk, 1988:239). Kata wati berarti prempuan, berbadan wanita, atau orang yang berstatus wanita. Sedangkan kata "gempeng" dalam kamus tidak dijelaskan. Dalam kamus hanya tercatat kata gempang, gempung, yang berasti hancur binasa, sima, gempur, musnah, dekdek. Sejarah Nasional Indonesia II (Kartodirdjo, 1975: 143 cat 53), menyebutkan kata gempeng diidentikkan dengan gempung, yang berarti remek atau hancur. M.M. Sukarto K. Atmojo, mengartikan kata gempeng (gempung) dengan remuk atau hancur (M.M. Sukarto K. Atmojo, 1972:3). Dengan demikian kata meragayawati dan gempeng bila digabungkan berarti; hancur leburnya perasaan Udayana karena jatuh cinta kepada seorang wanita. Peristiwa itu terjadi pada 899 Ç (ibid, 1975:143). Namun sejauh ini data yang tepat mengenai kapan berlangsungnya per-kawinan Udayana dengan Mahendradata belum diperoleh.

Prasasti pertama yang memuat nama Mahendradata yang bergelar Gunapriya-dharmapatni adalah prasasti Pucangan (Calcuta) bertahun 1041 M, pada baris 10 (berbahasa Sansekerta) (Kern,1919:85-114). Prasasti tersebut dikeluarkan olen Erlangga dengan maksud agar tidak ada orang lain yang berhak menaiki tahta kerajaan di Jawa Timur, kecuali dirinya. Hal tersebut disebabkan karena Erlangga secara siisilah meru. pakan keturunan Isana (Jawa Timur) dengan gelar Sri Maharaja Rake Halu Sri Lokeswara Dharmawangsa Airlangganantawikramottunggadewa. Sebenarnya apa yang dijelaskan oleh parasasti Pucangan (Calcuta) berbahasa Jawa kuna ini merupakan satu kelemahan bagi Erlangga sendiri sebab kedudukannya sebagai ahli warıs sementara orang tuanya berada di Bali. Dikatakan demikian karena Erlangga adalah putra sulung suami isteri Gunapriyadharmapatni dengan Dharma Udayana Warmadewa yang dilahirkan di Bali, pada tahun $1000 \mathrm{M}$ (Casparis: 1958:11; Kartodirdjo, 1975: 142 cat. 49).

\section{III}

Gunapriyadharmapatni dan Dharma Udayana Warmadewa memerintah Bali antara 989$1011 \mathrm{M}$. Pemerintahan selanjutnya dipegang oleh Sang Ratu Sri Sang Ajnadewi, sebagaimana tercantum dalam prasasti Sembiran, 938 C (Brandes, 1889: 48-49; Goris, 1954a:95-96); kemudian Marakata yang bergelar: Sri Dharmawangsa Wardana Marakata Pangkaja Statnuttunggadewa yang memerintah selama 1022-1025 M. dengan meninggalkan lima cakep parasasti, yaitu; (1) parasasti Batuan, 944 Ç; (2) Prasasti Sawan I/ Bila I, 945Ç; (3) Prasasti Tengkulak, 945Ç; (4) Prasasti Bwahan, 947Ç; dan (5) parasasti Kehen saka (?)

Berkaitan dengan uraian di atas tentu timbul pertanyaan mengapa bukan Erlangga yang menggantikan kedudukan Sang Ratu Sri Sang Ajnadewi. Sementara kedudukan Erlangga adalah putra sulung dari Gunapriyadharmapatni dan 
Dharma Udayana Warmadewa. Sementara itu menurut sistem hukum Hindu menyebutkan bahwa anak lakı-lakılah yang berhak atas harta warisan, meskipun tidak tertutup kemungkinan dalam keadaan tertentu anak perempuan dan kerabat-kerabat terdekat mempunyal peluang besar untuk menjadi ahli warıs (W. Wardha, 1992:9). Sistem Inı tercantum pada Manawaddharmasastra X 185 yang isınya antara Iain: bukannya saudara (darı ayah), pun bukannya ayah (dari pada ayah), melainkan anak-anak lakinya sendirılah yang berhak atas harta warısan; ayah (darı pada ayah) hanya berhak atas harta warisan anaknya yang tidak berputra, demikian pula saudara-saudaranya (Pudja, 1977: 68).

Hukum Hindu selaın bersifat menurun sebagaımana tercantum dalam Manawadharmasastra Juga menganut sistem pergantian dengan pengutamaan. Hai tersebut sepertı tertuang daiam Manawadharmasastra $\mid X 87$, yang menyeoutkan bahwa; harta warısan hendaknya diwariskan kepada keluarga sapinda yang terdekat terhadap pewarıs kemudian barulah kepada sakuiva dan akhirnya guru spiritual dan sisya seperguruannya (lbid, 1977: 69). Pasal ini menunjuk kan adanya 3 mandala keluarga dalam sistem pewarisan Hindu, yaitu (1) mandala yang tergolong sapinda, (2) mandala yang tergolong sakulya, (3) mandala guru spiritual dan teman seperguruannya

Dalam prasasti Pucangan (Calcuta) telah dijelaskan bahwa keberadaan Eriangga dı Jawa Timur adalah dalam rangka upacara pernikahannya dengan putri Dharmawangsa yang diduga kemenakan Gunaprıyadharmapatnı Ketika itu Er. langga berusıa 16 tahun Di pıhak laın dikatakan pada waktu berlangsungnya pesta perkawinan Erlangga dengan putri Dharmawangsa, tiba-tiba kerajaan Dharmawangsa mengalamı pralaya. Musıbah ını di prasastı Calcuta hanya terbaca sebagaı berıkut " $"$ kalaning pralaya ring yawaswipa, rikang sakakala 938 il prahara hall wurawarl maso mill sangke Iwaram, ekarnawa rupanikang sayawadwıpa rikangkala" Dapat dıterjemahan "ketika terjadınya pralaya di pulau Jawa pada tahun 938 C darı prahara Hajı Wurawarı ketıka ıa keluar darı Iwaram, seperti sebuah lautan keadaan seluruh pulau Jawa pada saat ıtu" (Kartodırdjo, 1975:102-103).

Serangan yang dilakukan oleh Haji Wurawarı menyebabkan terbunuhnya Dharmawangsa, dan Erlangga sempat melarıkan dırı ke dalam hutan. Kemudian pada tahun 1014 M, ıa dinobatkan menjadi raja dengan wisuddhajanma. Srı Maharaja Rake Halu Srı Lokeswara Dharmawangsa Erlangganantawikramottunggadewa. Penobatan ını mengesahkan Erlangga sebagal keturunan dınastı Isana di Jawa Timur. Upaya ını di. tempuh Dharmawangsa karena kemungkinan ıa tıdak mempunyal anak lain, kecualı Sri Sanggrama Wijaya. Itulah sebabnya ıa mengangkat anaknya menjadi sentana luh atau sentana rajeg. sehingga nantinya berhak mewarisi dan melanjutkan memegang pemerintahan. Sedangkan Erlangga yang berkedudukan sebagai sentana nyeburin, hanya memiliki hak-hak tertentu dan menduduiki tempat kedua dibandingkan dengan kedudukan Istrinya. Dengan demikian dapat dikatakan sı suami yang berbadan laki dalam hal tertentu berkedudukan sebagai seorang wanita Si suami berhak atas warisan darı mertuanya apabıla istrinya sebagai sentana luh atau sentana rajeg itu meninggai.

Kejadian inilah yang mungkın dialamı oleh Erlangga sehıngga haknya menjadi ahli waris di Bali menjadi hilang. Di pihak laın kecemasan timbul dari raja Haji Wurawari karena tampuk pemerintahan akan jatuh ketangan orang lain dengan dinasti yang lain pula (Wardha, 1992 12)

Pendapat ini dikuatkan oleh beberapa prasasti yang dikeluarkan oleh Marakata dan Anak Wungsu seperti parasasti Tengkulak, $945 \varnothing$ yang dikeluarkan oleh Marakata (Ginarsa, 1961: 4-15). |s| prasast। tersebut dapat dikutip sebagai berikut (1b.6.2a.l) "..-mangkai pwan manget kanang karaman I songan tambahan sapanambahan. an wka haji dewata sang lumah ring air wka sajalu strı, prasıddha kumalilir iang (2a.1) kulıt kakı sıniwı ring desa banten--.". Artınya (1 b 6.2ai) "--sekarang, ingatlah penduduk Desa Songan Tambahan (Tampaksiring) semuanya kepada seorang putera Bhatara/ Bhatarl suami isteri yang berhak menjadi ahli waris di dalam keturunannya, dihormati di desa-desa (pulau) Bali---"

IsI prasastl Tengkulak tersebut dimaksudkan untuk menunjukkan bahwa Marakata adaiah keturunan Gunapriyadharmapatni dan Dharma Udayana Warmadewa, yang berhak menjadi ahli waris dan tahta kerajaan di Bali. Hal ini juga diakui oleh warga penduduk Desa Songan Tambahan (Tampaksırıng). Satu pihak isi prasasti inı merupakan pengenalan dan pengukuhan, namun di plhak laın menyatakan bahwa Erlangga tıdak berhak menjadi ahli waris di Bali karena ia nyentana nyeburın di Jawa Timur.

Penegasan yang hampir sama terbaca puła pada prasasti Serai, 989 C (Wardha, 1992:42-43) yang diterbitkan oleh raja Anak Wungsu Pemerıntahannnya di Balı berlangsung darı tahun 1047 . 1077 M, dengan gelar: Paduka Haji Anakwungsunıra kalih Bhatari lumah I Burwan, Bhatara lumah i Bañuwka, yang secara tegas dinyatakan bahwa baginda adalah putera berdua (bersama) bhatarı yang disthanakan di Desa Burwan dan Bhatara Tirta. Kalımat di atas kemungkinan semacam penegasan bahwa orang tuanya berasai darı dinasti yang berlaınan. Di sampıng itu juga ditegaskan bahwa orang tuanya hanya 
mempunyai dua orang anak yaitu Marakata dan Anakungsu. Ayahnya disthanakan sebagai seorang kesatry, bukan seperti Ertangga se bagai soorang laki-laki yang berkedudukan wanita di Jawa Timur. Semua ini dibuktikan dari tulisan yang terbaca di percandian Gunung Kawi, Tampaksiring, Kabupaten Gianyar, yang bentunyi. "(r) wa (ne)kire" dan "Haji fumah ing jalu" Nardha, 1992: 14).

\section{IV}

Dari seluruh uraian di atas secara singkat dapat disimpulkan batwro selama pemerintahan Gunapriyadharmapatni dan Dharma Udayana Warmadewa, di dalam tubuh keluarganya senantiasa terjadi kericuhan. Hal ini dapat dilihat dalam prasasti-prasastinya pada permandian Jalatunda yaitu pada saat calon mempetai memadu cinta di Jawa Timur.

Solanjutnya keberadaan Erlangga di jawa Timur sebagai sentana nyeburin, dimana ia ber. indak sobagai seorang wanta yang pada akhitnya kehitangan haknya di Bali. Kalau dilikat secara sepintas sepertinya ada unsur politis, yaitu perluasan wilayah kekuasaan (ekspansi). Namun hal tersebut masih dipertanyakan lagi sebab kalau untuk pertuasan wilayah mengapa Erlangga rela meninggalkan warisannya di Rali.

Dari semua kemungkinan yang dapat diambil daiam uraian tersebut di atas menunjukkan bahwa kekuasaan Ertangga di Jawa Timur adaiah menjalin dan mengikat hubungan diantara dua dinasti yang berbeda.

\section{KEPUSTAKAAN}

Ardhana, I Gst Gde akk,1984, Pemerintahan Raja Udayana di Befi. Laporan Penelitian Universitas Udayana, Denpasar.

Boechañ, 1962, Rakyan Mahamantij i Hiko Sri Sanogramawijaya Dharmaprasadottunggedewi. Laporan Kongres limu Penge tahuan Nasional II him.55-84 Jakarta: Lipi

Brandes, J. 1889. De Koperen Platen van Semb; ran (exoloteng, Bali) TBG. No.33 him. 17.56 .

Budiastra, Putu. 1978. Prasasti Bwanhan, Kintamani-Bangli. Museum Bali. Direk. Museum - Ditjen Kebudayaan, Dep.Dik.Bud.
—,1880. Prasast Pura Tulukby, Batur Kintamani. Museum Bati. Direk. Museum - Dirjen Kebudayaan, Dep. Dik. Bud.

Casparis, GT. de., 1958. Airlangga. Pidato diccapkan pada peresmian Jabaten Guru Besar Dalam Mata Pelajaran sejarah Indonesia Lama dan 8ahasa Sonsekerta pada Perguruan Tinggi Pendidikan Guru Universitas Airlangga di Malang 26 April 1958

Gajestin, Th.P. 1964. "Basch" Studies on The Jalatunda Monument, Hinyaragarbha. A series of Articles on The Arceological Work and Studles of Prof. DR. F.D.K. Bosch. Mouton and Co. London. The Hague. Paris

Goris,R.1954a, b. Prasast Ball I dan II. Lembaga Banasa dan Budaya (Fakultot Sastro dan Filsafat) Universitas indonesia, NV. Masa Bary, Bandung.

1957. Dinasti Warmadewa dan Dama wangsa di Bafi. Terbit dalam Bahasa Budaya th. V.3 Lembaga Bahasa dan Budayaa Fak. Sastra UI, Jalurta.

1905, Ancient History of Balf Facukty of Letters Udayana Universitu, Denpasar.

Izamisma, 1992. Adat dan Upacara Perkawinan Mentawai Prayok Pengembangan Kebudayaan, Jakarta.

Juynboll.H.H.,1923, Oudjavaannsc - Nederiandche Woordenlisjst NV. Boekhandel en Drukkerij. E.J. Brill, Leiden

Kern, $H_{1}$ 1917. De Steen van den berg Penanggungan (Surabaya), thans in it indian Musoum to Calcute". Vo. VII 'S-Gravenhage, Martinus Nijhoff.

Koentjaraningrat, 1980. "Sistem-sistem Kekerabatan". Beberapa Pokok Amtropologi Sasial Penerbit, Dian Rakyat.

Korn, V.E. 1972. Hukum Adat Waris di Bali Diterjemahkan dan diberi catatan oleh: I Gde Wayan Pangkat. Fakultas Hukum Univensitas Udayana. Denpasar.

Pudja.I Gde, 1977. Hukum Kewarisan di Bali dan Lombok. Penerbit CV. Junasco Cet. 1 
Prawiroatmojo,S.,1981. Bausastra Jawa-Indonesia. I.ll. Gunung Agung, Jakarta, Ed.2.

Sartono Kartodirjo, dkk 1975. Sejarah Nasional Indonesia II. Dep. Dik Bud

Slamet Mulyana, 1979. Negarakertagama dan Tafsir Sejarahnya. Bhratara Karya Aksara. Jakarta.

Soeito Santoso, 1975 Calon Arang PN. Balai Pustaka

Tuuk. HN van der, et all. 1985. Transkriptie van Vier OudJavaansche Oorkonden op Koper Gevonden Op het Eiland Bali. Dalam TBG. XXX. Afl.6. Albrecht \& Co. Batavia

Wardha,I Wayan, 1987. "Menelusuri Tokok Ugasena". Terbit dalam Widya Pustaka Th. IV.3 Fak. Sastra Universitas Udayana, Denpasar.

-...-.-., 1992. Banu Wka (Lokasi Pedharman Reja Udayana), Laporan Penelitian Universitas Udayana, Denpasar.

Wardha, I Wayan, 1992. Orasi limiah dalam rangka HUT. Ke 34 dan BK XI Fak. Sastra, Universitas Udayana.

Warna, I Wayan, dkk. Kamus Bali - Kawi. Dinas Pendidikan Dasar Propinsi Daerah Tingkat \& Bali. 